\title{
Capillary Mats for Maintenance of Plants in the Retail Nursery
}

\author{
Ursula K. Schuch ${ }^{1,4}$, Jack J. Kelly ${ }^{2}$, and Trent Teegerstrom ${ }^{3}$
}

ADDITIONAL INDEX WORDS. water conservation, irrigation, container plants, economics

SUMMARY. Capillary mats and overhead sprinkler irrigation were used in a simulated retail environment to maintain annual and perennial plants in containers for various time periods during summer and winter. Combining the results from both seasons, four species with dense canopies had larger canopy sizes when maintained on the capillary mats, three species requiring more drainage had larger canopies with overhead irrigation, and five species were unaffected by irrigation systems. Substrate electrical conductivity was higher for some species in winter for plants on capillary mats, conserving fertilizer compared with overhead irrigation. Most species tolerated either irrigation system well. Water application was $71 \%$ less in summer and $62 \%$ less in winter to maintain plants on capillary mats compared with overhead irrigation. An economic analysis compared the investment required for setup and maintenance of plants in a retail situation using hand watering, overhead sprinkler, or capillary mat irrigation. The partial budget indicates that capillary mats are a labor-saving alternative to hand watering in a retail nursery and will compensate for the higher initial investment within less than 1 year. The overhead sprinklers are the most cost-effective system of the three because of less costly initial set-up and maintenance than the capillary mats; however, they are not a true alternative to hand watering in a retail situation because they interfere with customer traffic and worker activities.

$\mathrm{C}$ ontainer plants, especially those in 1-gal or smaller containers, are a perishable commodity when on display in the retail nursery. From the time of delivery by the wholesaler until purchased by customers, plants need to be maintained in good condition and require regular watering. Frequent turnover of product results in most businesses using limited automated overhead irrigation and relying primarily on hand watering to keep plants moist. Hand watering is the least efficient and most costly means of irrigation but efforts to automate irrigation have been greatly hindered by the necessary multiple irrigations per day during periods of high evaporative

\footnotetext{
We thank Soleno Textiles for the donation of the capillary mats for this study.

Mention of a trademark, proprietary product, or vendor does not constitute a guarantee of warranty of the product by the University of Arizona or the University of Arizona Cooperative Extension.

${ }^{1}$ Department of Plant Sciences, University of Arizona, Tucson, AZ 85721

${ }^{2}$ Pima County Cooperative Extension, University of Arizona, Tucson, AZ 85719

${ }^{3}$ Department of Agriculture and Resource Economics, University of Arizona, Tucson, AZ 85721

${ }^{4}$ Corresponding author. E-mail address: ukschuch@
} ag.arizona.edu demand, product turnover, customer traffic, and mixing of plants of different sizes and water requirements in displays.

Capillary mats have been used for producing floriculture (Bjerre, 1983; Morvant et al., 1998) and foliage (Neal and Henley, 1992) crops in the greenhouse, and their use has been advocated for maintaining plants in garden centers (Baldwin and Stanley, 1982). Capillary mats consist of absorbent fabric lined on the bottom with polyethylene film and covered on top with perforated polyethylene or similar material that minimizes water loss to evaporation. Water moves vertically into pots through the drainage holes once plants are placed on the mat and capillary action is established. One advantage of capil- lary mats is that plants of different size and water requirement can be placed on the same mat to meet different water needs. Empty areas of the mat are subject to minimal evaporative loss and can be restocked when practical. Uniform water application, always a problem with hand watering, and generation of large amounts of runoff water will not be an issue with capillary mats as long as the mat is on a level surface. Capillary mats can provide automated irrigation to different size plants, help with water conservation, and free retail nursery personnel from hand watering. Disadvantages of capillary mats include the higher initial installation costs, the need for a very flat surface to avoid puddling or dry spots on the mat, the need for a soil mix with porosity that allows the capillary rise of water, and cleaning and maintenance of the mats (Hodges and Haydu, 2001). According to a market analysis of this technology for wholesale nurseries in the southeastern United States, $\approx 25 \%$ of nurseries surveyed, especially larger firms with annual sales greater than $\$ 2.5$ million, were interested in the technology for wholesale production (Hodges and Haydu, 2001). Comparing the economic feasibility of capillary mats versus overhead irrigation for wholesale production, subirrigation tray, and microirrigation showed that using projected costs and profits over a 6-year period, capillary mats had the highest net return of the systems (Haydu et al., 2004).

The objective of this study was to compare water application and plant performance during the maintenance of plants in a simulated retail nursery environment using capillary mats or overhead spray irrigation. Partial budgets including initial investment and maintenance costs using capillary mats, overhead spray irrigation, or hand watering with a hose were compared during two seasons.

\begin{tabular}{llll}
\hline $\begin{array}{l}\text { Units } \\
\text { To convert U.S. to SI, } \\
\text { multiply by }\end{array}$ & U.S. unit & SI unit & $\begin{array}{l}\text { To convert SI to U.S., } \\
\text { multiply by }\end{array}$ \\
\hline 29.5735 & $\mathrm{fl} \mathrm{oz}$ & $\mathrm{mL}$ & 0.0338 \\
0.3048 & $\mathrm{ft}$ & $\mathrm{m}$ & 3.2808 \\
0.0929 & $\mathrm{ft}^{2}$ & $\mathrm{~m}^{2}$ & 10.7639 \\
0.0283 & $\mathrm{ft}^{3}$ & $\mathrm{~m}^{3}$ & 35.3147 \\
3.7854 & gal & $\mathrm{L}$ & 0.2642 \\
2.54 & inch $(\mathrm{es})$ & $\mathrm{cm}$ & 0.3937 \\
1 & $\mathrm{mmho} / \mathrm{cm}$ & $\mathrm{dS} \cdot \mathrm{m}^{-1}$ & 1 \\
1 & $\mathrm{ppm}$ & $\mathrm{mg} \cdot \mathrm{L}^{-1}$ & 1 \\
$\left({ }^{\circ} \mathrm{F}-32\right) \div 1.8$ & ${ }^{\circ} \mathrm{F}$ & ${ }^{\circ} \mathrm{C}$ & $\left(1.8 \times{ }^{\circ} \mathrm{C}\right)+32$
\end{tabular}




\section{Materials and methods}

Plant performance and Water APPLICATION. For the first experiment, plants ready for retail sales were obtained from local nurseries and on 4 Aug. 2005 were placed in a simulated retail environment in a retractable roof greenhouse at the University of Arizona in Tucson under $50 \%$ shade. The roof was fully retracted from 0600 to $1000 \mathrm{HR}$ and from 1400 to $1800 \mathrm{HR}$ unless weather conditions were severe. Minimum/ maximum average monthly temperatures in the structure were: $23.7 /$ $39.5^{\circ} \mathrm{C}$ in August, $21.4 / 39.7^{\circ} \mathrm{C}$ in September, $14.9 / 33.4{ }^{\circ} \mathrm{C}$ in October, and $7.7 / 28.5{ }^{\circ} \mathrm{C}$ in November. Perennials in 1-gal pots used were gopher plant (Euphorbia rigida), angelita daisy (Hymenoxis acaulis), pink gaura (Gaura lindheimeri), and blue chihuahuan sage (Salvia chamaedroides). Annuals in 6-cell packs (150 mL per cell) used were vinca (Catharanthus roseus) and verbena (Verbena peruviana). 'Red' salvia (Salvia splendens) was growing in 4inch-diameter pots $(610 \mathrm{~mL})$. Plants were placed on benches with a capillary mat (Aquamat S10; Soleno Textiles, Laval, Quebec, Canada) or overhead spray emitters $(45-\mathrm{cm}$ risers; Agrifim, Lindsay, CA) with Varijet microsprinklers (Pepco, Ontario, CA). Dimensions of benches were $2.8 \times 1.6 \mathrm{~m}$ and dimensions of capillary mats were $2.8 \times 1.5 \mathrm{~m}$. Plants were fertigated once every $12 \mathrm{~d}$ at a rate of $510 \mathrm{mg} \cdot \mathrm{L}^{-1}$ nitrogen $(15 \mathrm{~N}-$ $12.9 \mathrm{P}-12.5 \mathrm{~K}$ plus micronutrients; Scotts Miracle-Gro Products, Marysville, $\mathrm{OH})$. Annuals were maintained for $33 \mathrm{~d}$ and perennials for $118 \mathrm{~d}$. Senescent flower stalks of angelita daisy and pink gaura were cut back, which accounts for the smaller height and canopy size at the last measurement day compared with day 25 when they were in full bloom. The study was replicated on three benches for each irrigation system where four pony packs of each annual species, five salvia in 4-inch pots, and five 1gal plants of perennials were arranged in a completely randomized block design per bench. Plant height and size index calculated as (height $\times 2$ widths $) \div 3$ were determined after 10 and $25 \mathrm{~d}$ for all plants, and after $118 \mathrm{~d}$ for perennials in 1-gal containers. Visual quality of leaves and flowers was recorded after 28 d based on a rating system from 1 to 4 ( $1=0 \%$ to $10 \%, 2=11 \%$ to $50 \%, 3=$ $51 \%$ to $90 \%$, and $4=91 \%$ to $100 \%$ of green, healthy leaves or shoots with flowers at anthesis or flower buds).

Plants were watered with overhead irrigation spray or capillary mats. Application times changed based on weather conditions, which affected plant water use. Water was applied three times per day at 0800,1200 , and $1600 \mathrm{HR}$; overhead sprinklers were set to turn on between 8 and $12 \mathrm{~min}$, and capillary mats were supplied with water between 5 and $8 \mathrm{~min}$ during each irrigation event. The amount of water applied was recorded with flow meters that were connected to each bench.

Substrate electrical conductivity (EC) was recorded 11,19 , and $32 \mathrm{~d}$ after the onset of the experiment with a direct soil probe (Field Scout Direct Soil EC Meter; Spectrum Technologies, Plainfield, IL). Measurements were taken within $2 \mathrm{~h}$ after irrigation with the tip of the probe $1 \mathrm{~cm}$ above the bottom of the container and two measurements per pack or 1-gal pot were averaged.

A second experiment was conducted from 25 Jan. 2006 until 15 Feb. 2006 in the same location using the same experimental setup as previously described. Species used were snapdragon (Antirrbinum majus), pansy (Viola $\times$ wittrockiana), stock (Mattbiola incana), spinach (Spinacia oleracea), and swiss chard (Beta vulgaris). Annuals in 6-cell packs ( $150 \mathrm{~mL}$ per cell) were ready for retail sales at the beginning of the experiment. Each cell pack was considered one experimental unit and four replicates per species were arranged on three benches in a completely randomized design. The roof and side-walls of the retractable roof greenhouse were kept open from 0800 until $1600 \mathrm{HR}$ and were closed the rest of the time. Minimum daily temperatures ranged from -2 to $6{ }^{\circ} \mathrm{C}$ and maximum temperatures ranged from 21 to $33{ }^{\circ} \mathrm{C}$. Plants were fertigated once per week at a rate of $510 \mathrm{mg} \cdot \mathrm{L}^{-1} \mathrm{~N}$ (15N-12.9P-12.5K plus micronutrients; Scotts Miracle-Gro Products). Substrate EC was measured 1 $\mathrm{d}$ before and $2 \mathrm{~d}$ after each fertigation as described above.
Irrigation was supplied at 0800 and $1600 \mathrm{HR}$ each day for $3 \mathrm{~min}$ for the capillary mat and $4 \mathrm{~min}$ for the overhead sprinkler. On $4 \mathrm{~d}$ weather conditions were cloudy and irrigation times were reduced by 1 or 2 min per irrigation event. Canopy height and widths were measured at the beginning and at the conclusion of the experiment and size index was calculated as previously described.

Data for both experiments were analyzed with analysis of variance comparing irrigation treatment within species when interactions between species and treatments were significant (SAS Institute, Cary, NC).

Financial anAlysis. A partial budget analysis was calculated to evaluate the economic trade-offs between hand irrigation, capillary mat, and overhead sprinkler irrigation. Partial budgeting is a method of organizing data and information about the cost and benefits from some change in the technologies being used in an operation with the aim to estimate the change that will occur in operations' profit or loss from some change in the current operation plan (Boehlje and Eidman, 1984). Costs for irrigation systems for the overhead sprinkler and capillary mat systems included all components necessary to bring the irrigation from an existing riser to individual benches including PVC pipe and parts, black poly tube, and components on top of the benches such as PVC pipe and parts, spray heads, and the capillary mats with end caps. The overhead sprinkler and the capillary mat system included an irrigation clock for automated watering. Labor for system installation was assumed to be $0.5 \mathrm{~h}$ per bench for the overhead sprinklers and $\mathrm{l} h$ per bench for the capillary mats, which included leveling each bench. Initial investments for hand watering included an industrialstrength 5/8-inch-diameter hose $75 \mathrm{ft}$ long and a 30-inch-long commercial-grade aluminum wand. No installation costs were budgeted for hand watering because faucets were assumed to be in the area.

Partial budgets were calculated for $180 \mathrm{~d}$ each of summer and winter season based on the different evaporation demand and irrigation needs during the two seasons. Water needs were based on the results from the experiments previously described, 
and water quantity for hand watering was estimated to be 1.5 times the amount used for overhead sprinkler irrigation. Labor for hand watering was estimated based on information from a retail garden center $(S$. Calhoun, pers. comm.). Hand watering was assumed to require $2 \mathrm{~h}$ in the summer and $\mathrm{l} \mathrm{h}$ in winter daily to water seven benches of the size used in our experiments. We assumed 15 min per day to control proper function of the irrigation clock and overhead sprinklers for seven benches. Capillary mats were assumed to require $15 \mathrm{~min}$ daily to control for proper function of the system and 4 $h$ per month in summer and $3 \mathrm{~h}$ per month in winter to clean the mats.

Labor costs were assumed to be \$9.26 per hour based on the Arizona Agricultural Statistic Service average wage rate for all hired workers in agriculture from 8 Jan. to $15 \mathrm{Apr}$. 2006 (U.S. Department of Agriculture, 2006). The rate for water cost was based on the Tucson commercial water rate for all usage from 7 Aug. 2006 and was $\$ 1.54$ per cubic foot (City of Tucson, 2007).

\section{Results and discussion}

Plant Performance and Water Application. Size index of gopher plant and pink gaura after $118 \mathrm{~d}$ of overhead irrigation was larger than for plants under capillary mat irrigation (Table 1), possibly because the species are adapted to dry conditions and may thrive better when drying out between irrigations. Canopy size of angelita daisy was affected by irrigation treatments early in the experiment, but no difference was found after plants were cut back after flower senescence and regrew. Conversely, canopy size of salvia and verbena was larger after $25 \mathrm{~d}$ of capillary mat compared with overhead irrigation (Table 1), most likely because the relatively large plants in six-cell packs or 4-inch pots, respectively, benefited from the almost constant moisture on the capillary mat, whereas plants under overhead irrigation suffered from intermittent drought stress between irrigations. Canopy size of blue chihuahuan sage and vinca were unaffected by the irrigation treatments.

Survival of vinca was lowest among all species and was low under both irrigation systems (Table 1). Phytophthora foliar blight (Phytophthora cactorum) was identified on the diseased plants. The disease became apparent very soon after plants had been acquired from the nursery and was likely present at the time of purchase. A total of four angelita daisy plants died and phytophthora root rot (Phytophthora cactorum) was identified on infected samples. Good drainage is essential for this species (Irish, 2006), and plants are known to decline quickly when overwatered. Two plants of blue chihuahuan sage irrigated with capillary mats died in August from rhizoctonia root rot
(Rhizoctonia solani). Although one or more of the disease organisms were present on each of the three replicate benches, there was no evidence that the organisms spread to other plants located on the same mat based on our observation that disease was localized and did not visibly affect other plants. Flower production of angelita daisy was reduced under the capillary mat conditions compared with overhead spray (Table 1) while flowering of the other species remained unaffected. Visual evaluation of leaves showed no difference between species and irrigation treatments, except for calcium deposits observed on plants with glossy leaves such as vinca.

Between $69 \%$ and $72 \%$ less water was applied to plants irrigated with capillary mats compared with overhead irrigation (Table 2). Over the 3 -month study period, an average of $71 \%$ less water was applied to maintain plants with capillary mats compared with overhead irrigation. Similar water savings of $75 \%$ were realized for foliage plant production when capillary mats were used compared with overhead irrigation (Neal and Henley, 1992). Substrate EC measurements ranged from 0.1 to $1.0 \mathrm{dS} \cdot \mathrm{m}^{-1}$ and no difference between irrigation treatments for each species was noted (data not shown).

Plants used in the second experiment conducted in winter had similar height and canopy size at the beginning of the experiment, but after

Table 1. Survival, appearance of flowers, height, and size of annuals and perennials maintained with capillary mat (CM) or overhead spray (OS) irrigation in a simulated retail environment.

\begin{tabular}{|c|c|c|c|c|c|c|c|c|c|}
\hline \multirow[b]{2}{*}{ Species } & \multirow[b]{2}{*}{ Irrigation } & \multirow{2}{*}{$\begin{array}{c}\text { Survival } \\
(\%)\end{array}$} & \multirow{2}{*}{$\begin{array}{c}\text { Flower rating } \\
(1-4 \text { scale })^{\mathrm{z}}\end{array}$} & \multicolumn{3}{|c|}{$\mathrm{Ht}(\mathrm{cm})^{\mathrm{y}}$} & \multicolumn{3}{|c|}{ Size index ${ }^{\mathrm{x}}$} \\
\hline & & & & $10 \mathrm{~d}$ & $25 \mathrm{~d}$ & $118 \mathrm{~d}$ & $10 \mathrm{~d}$ & $25 \mathrm{~d}$ & $118 \mathrm{~d}$ \\
\hline Gopher plant & $\mathrm{CM}$ & 100 & - & 15.2 & $16.6^{*}$ & $27.7^{*}$ & 944 & 1,248 & $4,757^{*}$ \\
\hline Blue chihuahuan sage & $\mathrm{CM}$ & 87 & 3.8 & 36.6 & 42.1 & 42.6 & 5,219 & 8,570 & 10,431 \\
\hline Blue chihuahuan sage & OS & 100 & 4.0 & 39.1 & 44.1 & 40.1 & 5,963 & 10,741 & 11,466 \\
\hline Angelita daisy & $\mathrm{CM}$ & 80 & $1.4^{*}$ & $21.0 *$ & 22.0 & 11.9 & 986 & $1,816^{*}$ & 775 \\
\hline Pink gaura & OS & 100 & 4.0 & 39.7 & 45.2 & 30.5 & 8,076 & 12,287 & 9016 \\
\hline Salvia & $\mathrm{CM}$ & 100 & 3.7 & 28.7 & 42.1 * & - & 2,632 & 7,941 * & - \\
\hline Salvia & OS & 100 & 3.3 & 27.7 & 37.2 & - & 2,349 & 4,979 & - \\
\hline Verbena & $\mathrm{CM}$ & 100 & 3.4 & 16.4 & $21.5^{*}$ & - & 2,701 & $6,367^{*}$ & - \\
\hline Verbena & OS & 100 & 3.4 & 15.4 & 17.0 & - & 2,679 & 4,713 & - \\
\hline
\end{tabular}

${ }^{\mathrm{z}} 1=0 \%$ to $10 \%, 2=11 \%$ to $50 \%, 3=51 \%$ to $90 \%$, and $4=91 \%$ to $100 \%$ of shoots with flowers at anthesis or flower buds.

${ }^{\mathrm{y}} \mathrm{l} \mathrm{cm}=0.3937$ inch

${ }^{x}$ Size index $=($ height $\times 2$ widths $) \div 3$.

*Indicates a significant difference within a column at $P<0.05$ between $O S$ and $C M$ for a species based on analysis of variance. 
$21 \mathrm{~d}$, pansies were $10 \%$ taller and had a $17 \%$ greater size index when maintained on capillary mats versus overhead sprinklers. Swiss chard plants responded similarly with a $10 \%$ greater size index at the end of the experiment. Canopy size of the other three species was unaffected by the irrigation treatments. Canopies of pansies were extremely dense with horizontal leaves overlapping, tightly covering the media surface and creating a barrier for water from overhead sprinklers to penetrate into the media, whereas water uptake from capillary mats from the bottom of the pot was unimpeded. Swiss chard had the largest size index, and although leaves were upright, they were closely packed, which probably caused some deflection of the overhead water applied.

Conductivity in the substrate was higher for plants on the capillary mats for one sampling in snapdragon, two sampling dates in stock, and four or more dates for the other species (Table 3). Leaching through overhead irrigation decreases fertility in the root zone (Neal and Henley, 1992), whereas leaching is eliminated in capillary mat systems and fertilizer is conserved. In a previous study, higher fertilizer rates were applied to plants under overhead irrigation compared with those irrigated via capillary mats to compensate for the excessive leaching (Neal and Henley, 1992). EC values measured in this study with the direct soil probe indicate low fertility in some cases, however, they were found to be consistently lower in a study by Scoggins and van Iersel (2006) compared with the traditional pour-through method (Wright, 1986). However, no deficiency symptoms were observed in any of the plants, and all species increased significantly in height and size during the experiment.

Water application was lower for capillary mats with $68 \mathrm{~L}$ per bench per week versus $182 \mathrm{~L}$ per bench per week for overhead irrigation. Although the $62 \%$ water savings in winter were close to the $71 \%$ lower application of water in summer, savings in summer are far more substantial because of the greater amount of water used during the period of high evaporative demand.

Economic analysis. Total system cost including installation for the three irrigation systems on a per table basis ranged from $\$ 9.14$ for the

Table 2. Water application to maintain container plants with two types of irrigation. Means are the daily average of water applied during $27 \mathrm{~d}$ (consecutive) to maintain container plants on one bench.

\begin{tabular}{lcc}
\hline & $\begin{array}{c}\text { Overhead spray } \\
\left(\mathbf{L} \cdot \mathbf{d}^{-1} \text { per } \text { bench }\right)^{\mathbf{z}}\end{array}$ & $\begin{array}{c}\text { Capillary mat } \\
\left(\mathbf{L} \cdot \mathbf{d}^{-1} \text { per bench }\right)\end{array}$ \\
\hline August/September & $118 \mathrm{a}^{\mathrm{y}}$ & $32.9 \mathrm{~b}$ \\
September/October & $116 \mathrm{a}$ & $32.6 \mathrm{~b}$ \\
October/November & $82 \mathrm{a}$ & $25.8 \mathrm{~b}$ \\
\hline
\end{tabular}

${ }^{2} 1 \mathrm{~L}=0.2642$ gal.

${ }^{y}$ Means within a row followed by different letters are significantly different at $P<0.05$ based on analysis of variance. hand-watering system to $\$ 134.56$ for the capillary mat system (Table 4). The largest operating expense item for all of the systems was labor, ranging from a high of $\$ 466.70$ per table for hand watering to a low of $\$ 66.67$ for the overhead sprinkler system.

A comparison between systems for the summer and winter time periods showed that the hand-watering option performed poorest in both seasons, costing an additional \$44.83/ $\mathrm{m}^{2}$ over the overhead sprinklers and $\$ 35.20 / \mathrm{m}^{2}$ over the capillary mat option in the summer trial and $\$ 12.07 / \mathrm{m}^{2}$ and $\$ 2.91 / \mathrm{m}^{2}$, respectively, in the winter trial (Table 5). Savings from labor cost in the handwatering option was a significant component in the positive returns for the other systems, including covering the cost of materials and installation of the overhead sprinkler and capillary mat systems as reported in Table 4 .

A comparison between the overhead sprinkler system and the capillary mat system showed the overhead sprinkler system as more cost effective at $\$ 10.08$ less per square meter for the summer and \$9.62 less per square meter for the winter than the capillary mat system (Table 5). Labor savings when using overhead versus capillary mats were \$31.67 and \$21.67 per table for the summer and winter, respectively. The labor difference between these two automated systems can be attributed to the extra $4 \mathrm{~h}$ per month needed for cleaning the capillary mats. Water usage for the capillary mat system versus overhead was $15,165 \mathrm{~L}$ less per bench during the summer and 2,934 L less per bench

Table 3. Electric conductivity (EC) measured with a direct soil probe in growing substrate of annuals maintained with capillary mats (CM) or overhead sprinklers $(O S)$ in a simulated retail environment for 21 d. Plants were fertilized on days 7 and 14.

\begin{tabular}{|c|c|c|c|c|c|c|c|}
\hline \multirow[b]{2}{*}{ Species } & \multirow[b]{2}{*}{ Irrigation } & Day 2 & Day 6 & Day 9 & Day 13 & Day 16 & Day 20 \\
\hline & & \multicolumn{6}{|c|}{$\mathrm{EC}\left(\mathrm{dS} \cdot \mathrm{m}^{-\mathbf{1}}\right)^{\mathrm{z}}$} \\
\hline Pansy & $\mathrm{CM}$ & 0.66 & 0.50 * & $0.60 *$ & $0.59 *$ & $1.14^{*}$ & $0.62 *$ \\
\hline Snapdragon & $\mathrm{CM}$ & $0.57^{*}$ & 0.37 & 0.44 & 0.37 & 0.93 & 0.53 \\
\hline Snapdragon & OS & 0.34 & 0.28 & 0.39 & 0.38 & 0.65 & 0.48 \\
\hline Spinach & $\mathrm{CM}$ & 0.64 & $0.52 *$ & $0.47^{*}$ & 0.38 & $1.09 *$ & $0.72 *$ \\
\hline Stock & OS & 1.05 & 0.66 & 0.62 & 0.63 & 1.35 & 0.98 \\
\hline Swiss chard & $\mathrm{CM}$ & $0.63^{*}$ & $0.44^{*}$ & $0.48^{*}$ & 0.32 * & $0.80^{*}$ & $0.47^{*}$ \\
\hline Swiss chard & OS & 0.48 & 0.23 & 0.32 & 0.21 & 0.38 & 0.20 \\
\hline
\end{tabular}

${ }^{\mathrm{z}} \mathrm{l} \mathrm{dS} \cdot \mathrm{m}^{-1}=1 \mathrm{mmho} / \mathrm{cm}$.

An asterisk indicates a significant difference within a column at $P<0.05$ between $\mathrm{OS}$ and $\mathrm{CM}$ for a species based on analysis of variance. 
Table 4. Assumptions for the partial budget analysis to compare a capillary mat system, overhead sprinklers, and hand watering for maintenance of plants in a simulated retail environment.

\begin{tabular}{lccc}
\hline & Capillary mat & $\begin{array}{c}\text { Overhead } \\
\text { sprinkler }\end{array}$ & $\begin{array}{c}\text { Hand } \\
\text { watering }\end{array}$ \\
\hline System cost per bench $(\$)$ & 134.56 & 89.45 & 9.14 \\
Installation cost per bench $(\$)$ & $9.26^{\mathrm{z}}$ & 4.63 & 0.0 \\
Labor per bench $(\mathrm{h})$ & 1.0 & 0.5 & 0.0 \\
& \multicolumn{2}{c}{ Summer season (per 180 d) } \\
Labor cost per bench $(\$)$ & 98.34 & 66.67 & 466.70 \\
Labor per bench $(\mathrm{h})$ & 11.0 & 7.0 & 50.0 \\
Water cost per bench $(\$)$ & $3.21^{\text {y }}$ & 11.45 & 17.13 \\
Water per bench $(\mathrm{L})^{\mathrm{x}}$ & 5,895 & 21,060 & 31,500 \\
& \multicolumn{4}{c}{ Winter season $($ per $\mathbf{1 8 0}$ d) } & \\
Labor cost per bench $(\$)$ & 88.34 & 66.67 & 233.35 \\
Labor per bench $(\mathrm{h})$ & 10.0 & 7.0 & 25.0 \\
Water cost per bench $(\$)$ & 0.95 & 2.55 & 3.82 \\
Water per bench $(\mathrm{L})$ & 1,746 & 4,680 & 7,020 \\
\hline
\end{tabular}

${ }^{2}$ Arizona Agricultural Statistic Service average wage rate for all hired workers from 8 Jan. to 15 Apr. 2006 was $\$ 9.26$ per hour.

Tucson commercial water rate for all usage 7 Aug. 2006 was $\$ 1.54 / \mathrm{ft}^{3}\left(\$ 54.385 / \mathrm{m}^{3}\right)$ (City of Tucson, 2007). ${ }^{\mathrm{x}} \mathrm{l} \mathrm{L}=0.2642 \mathrm{gal}$

Table 5. Summary comparison of partial budgets for three irrigation systems for two seasons.

\begin{tabular}{|c|c|c|c|}
\hline & $\begin{array}{c}\text { Capillary } \\
\text { mat vs. } \\
\text { hand watering }\end{array}$ & $\begin{array}{c}\text { Capillary } \\
\text { mat vs. } \\
\text { overhead sprinkler }\end{array}$ & $\begin{array}{c}\text { Overhead } \\
\text { sprinkler vs. } \\
\text { hand watering }\end{array}$ \\
\hline \multicolumn{4}{|c|}{ Summer season (per $180 \mathrm{~d}$ ) } \\
\hline Savings per bench $(\$)$ & 163.55 & -46.83 & 208.26 \\
\hline $\begin{array}{l}\text { Savings per unit area } \\
\qquad\left(\$ / \mathrm{m}^{2}\right)^{\mathrm{z}}\end{array}$ & 35.203 & -10.079 & 44.831 \\
\hline $\begin{array}{l}\text { Water savings per } \\
\text { bench }(\$)\end{array}$ & 97.48 & 57.73 & 39.74 \\
\hline $\begin{array}{l}\text { Water savings per } \\
\text { bench }(\mathrm{L})^{\mathrm{z}}\end{array}$ & 25,605 & 15,165 & 10,440 \\
\hline $\begin{array}{l}\text { Labor savings per } \\
\text { bench }(\$)\end{array}$ & 368.36 & -31.67 & 400.03 \\
\hline \multicolumn{4}{|c|}{ Winter season (per $180 \mathrm{~d})$} \\
\hline Savings per bench $(\$)$ & 13.53 & -44.68 & 56.09 \\
\hline $\begin{array}{l}\text { Savings per unit area } \\
\qquad\left(\$ / \mathrm{m}^{2}\right)\end{array}$ & 2.908 & -9.622 & 12.073 \\
\hline $\begin{array}{l}\text { Water savings per } \\
\text { bench }(\$)\end{array}$ & 20.08 & 11.17 & 8.91 \\
\hline $\begin{array}{l}\text { Water savings per } \\
\text { bench }(\mathrm{L})\end{array}$ & 5,274 & 2,934 & 2,340 \\
\hline $\begin{array}{l}\text { Labor savings per } \\
\text { bench }(\$)\end{array}$ & 145.01 & -21.67 & 166.68 \\
\hline
\end{tabular}

${ }^{2} \$ 1.00 / \mathrm{m}^{2}=\$ 0.0929 / \mathrm{ft}^{2}, \mathrm{l} \mathrm{L}=0.2642 \mathrm{gal}$.

during the winter. Water savings are even greater when capillary mat systems are compared with hand watering. These substantial savings in water have little effect on the partial budget, which is dominated by initial system costs and labor costs and the low price for water. With increasing concerns about water availability and possible price increases, retail nurseries should consider the pros and cons when selecting irrigation systems and practices.

Hand watering is currently the most common practice for maintaining plants in retail nurseries. Capillary mats are a viable alternative to hand watering because they can be used for irrigation at any time during business hours without disrupting a display area. Overhead sprinkler systems are generally not used because if watering is necessary during business hours, the spray would interfere with customers and staff. Overhead sprinklers were used in the experiment because they provided an alternative to daily hand watering, and they are used in production nurseries and in holding areas of retail nurseries where plants are not on display for customers. Further questions not addressed in this study are whether plants irrigated overhead with a hose or those with capillary mats are more attractive to customers, and whether there is a difference in the number of plants that are discarded.

In summary, irrigation with capillary mats compared with overhead spray has the potential for saving up to $70 \%$ of water compared with overhead spray and even more compared with hand watering that is applied to maintain plants under retail conditions. Plant performance of plants that are relatively large for the container and that require frequent irrigation may be enhanced when maintained on capillary mats, whereas plants that require good drainage and drying out between irrigations may be better suited for long-term maintenance under overhead irrigation. Although EC in the substrate increased in winter for plants on the capillary mats, they never reached injurious levels and conserved mineral elements that were leached under overhead irrigation. Most species tolerated both irrigation systems well. The partial budget indicates that capillary mats are a labor-saving alternative to hand watering in a retail nursery and will compensate for the higher initial investment within less than 1 year. The overhead sprinkler is the most cost-effective system of the three because of a less costly initial set-up and maintenance than the capillary mats. However, overhead sprinklers are not a true alternative to hand watering in a retail situation because they interfere with customer traffic and staff activities.

\section{Literature cited}

Baldwin, I. and J. Stanley. 1982. The garden centre manual. Timber Press, Portland, OR

Bjerre, H. 1983. Pot plant growing on a capillary mat covered with a perforated polyethylene foil. Acta Hort. 133:161164. 
Boehlje, M.D. and V.R. Eidman. 1984. Farm management. Wiley, New York.

City of Tucson, Department of Water. 2007. Current water rate schedules. 22 June 2007. <http://www.ci.tucson.az. us/water/rates.html>.

Haydu, J.J., R.C. Beeson, and J. Caron. 2004. Economics of five irrigation technologies for container-grown Viburnum odoratissimum. Acta Hort. 664:309315.

Hodges, A.W. and J.J. Haydu. 2001. Market analysis of the capillary mat irrigation technology for wholesale nurseries in the southeastern United States. Proc.
South. Nursery Assn. Res. Conf. 46:570573.

Irish, M. 2006. Perennials for the southwest. Timber Press, Portland, OR.

Morvant, J.K., J.M. Dole, and J.C. Cole. 1998. Irrigation frequency and system affect poinsettia growth, water use, and runoff. HortScience 33:42-46.

Neal, C.A. and R.W. Henley. 1992. Water use and runoff comparisons of greenhouse irrigation systems. Proc. Florida State Hort. Soc. 105:191-194.

Scoggins, H.L. and M.W. van Iersel. 2006. In situ probes for measurement of electrical conductivity of soilless substrates: Effects of temperature and substrate moisture content. HortScience 41:210-214.

U.S. Department of Agriculture. 2006. Arizona agricultural statistics. 8 Nov. 2007. <http://www.nass.usda.gov/ Statistics_by_State/Arizona/Publications/ Annual_Statistical_Bulletin/05bul/pdf/ pg00E_TOC.pdf>.

Wright, R.D. 1986. The pour-through nutrient extraction procedure. HortScience 21:227-229. 